\title{
Hyperreality in Dance Learning in Grade XI Computer and Network Engineering at Vocational High School Diponegoro 1 Jakarta
}

\author{
Michelia Champaca N. Setyoputri ${ }^{1,}{ }^{*}$ Dra. Rumiwiharsi, M.Pd. ${ }^{2,}$ Prayogi Wijaksono ${ }^{1}$ \\ ${ }^{1,2}$ Arts Education, Graduate School, Universitas Negeri Yogyakarta \\ * Corresponding author. Email: champaca94@gmail.com
}

\begin{abstract}
This study investigated a phenomenon of dance learning at Vocational High School (VHS) Diponegoro 1 Jakarta in Grade XI Computer and Network Engineering with 24 male and 1 female student. In general, boys tend to be tough and assertive; therefore, they lack the abilities to process their bodies, particularly to dance. Male students need physical exercise to improve their psychomotor skills and insight on folklores. This study focused on the hyperreality in dance learning at VHS Diponegoro 1 Jakarta, where the class was dominated by male students. The classic thought in society assumes that if a boy dances or performs a dance, he will be addressed "sissy". The finding based on the triadic perspective at the semiotic initial level stated by Charles Sanders Pierce (Hoed 2007, Piliang 2018), which was linked to the writing method used in this study, is descriptive qualitative. This study aimed to elaborate the dance learning for male students on exploration and improvisation materials to produce the types and characters of movements that were appropriate for male students particularly in dance learning of Culture and Arts subject. This study revealed the learning outcomes of dance learning in exploration and improvisation materials that include types of movement, movement characters, and types of drama with the theme of Ramayana, using a constructivist learning theory.
\end{abstract}

Keywords: Hyperreality, dance learning, semiotics

\section{INTRODUCTION}

Vocational High School (VHS) has become one of the most important elements in the industrial world based on the areas studied. The specific aim of vocational secondary education is to produce productive human beings who can work independently. Vocational high schools organize educational programs according to the kinds of employment (Government Regulation No. 29 Year 1990 concerning Vocational Secondary Education Chapter 1 Article 3) and provide a Basic Framework and Structure of Vocational Secondary School Curriculum (Regulation of the Minister of Education and Culture of the Republic of Indonesia No. 70 Year 2013). In short, Vocational High School indirectly helps survive and provide job opportunities for students after graduating from school. Vocational High School with more male students has the same rights and obligations as Senior High Schools, in terms of arts education learning. Arts education is a subject to develop the students' potentials in vocational high schools with a majority of male students. It is able to stimulate the students' feeling/sensitivity. Particularly, culture and arts education can enrich arts knowledge in Indonesia, manage the students' feelings and imagination related to the response to arts and aesthetics.

Dance education is one of the art studies, which plays a role in fostering students' logic, ethics, and aesthetics through the introduction of both traditional and nontraditional art materials. The Culture and Arts subject in the field of dance for the exploration and improvisation materials is employed as an evaluation of students in creating arts. 
Teaching Culture and Arts subject (Dance) to students at VHS Diponegoro 1 Jakarta is a challenge which is not easy to make male students move their bodies. With this phenomenon, this writing is to find out hyperreality in dance learning for the exploration and

In a study, the researchers employed an appropriate method to collect valid data., i.e. a qualitative study which is widely used in research. Descriptive qualitative research contains data quotes to illustrate the presentation of the report [1]. Qualitative research differs from other research in several ways. Williams mentions three main points: basic views of axioms about the nature of reality, the relationship between research and researchers, the possibility of making generalizations, the possibility of building causal relationships, and the roles of values in research. It provides two characteristics of the qualitative research approach, and the three processes to carry out the research [2]. Furthermore, qualitative research is used to describe and analyze phenomena, events, social activities, attitudes, beliefs, perceptions, and people individually or in groups [3].

The study used a qualitative method to describe a hyperreality in dance learning for male students at VHS Diponegoro 1 Jakarta. The research emphasized the process and meaning of social reality which is not rigorously tested in terms of quantity or frequency.

The focus of the descriptive qualitative research explained how male students in vocational schools could perform a traditional dance from Indonesia. The research had been conducted for four months from September to December 2016. There were two types of data in this study, i.e. primary and secondary data.

The primary data were obtained by conducting indepth interviews with two informants. The research informants were selected to ask about student interest in learning skills, especially dance. The other informant was the Culture and Arts (Dance) Teacher, to find out the process of implementing dance learning

\section{DISCUSSION}

\subsection{Hyperreality}

Baudrillard's writings contain the features of a postmodern theory. Baudrillard writes about a world that is built up from a mess of values, facts, signs, images, and codes.

Reality no longer has any reference, except for the simulacra itself. In the postmodern era, the principle of simulation becomes the commander, where reproduction (with information technology, communication, and knowledge industry) replaces the principle of production, while the play of signs and images dominates almost all human communication processes. In Baudrillard's book Simulations, the improvisation of dance movements in Grade XI at VHS Diponegoro 1 Jakarta.

\section{METHOD}

and the impacts associated with the majority of male students in Grade XI Computer and Network Engineering.

Interviews with the three informants were conducted at VHS Diponegoro 1 Jakarta school. In addition, the secondary data were obtained from journals, book literature, publication data, and indirect observations on electronic and printed media.

This study also applied a semiotic approach by Charles Sanders Peirce. Semiotics is a study of signs and everything related to symbols, how to function (syntactic semiotics), and the relationship between signs (semantic semiotics) and examines the sender and recipient by those who use signs (paradigmatic semiotics). In the context of a sign, Peirce states that the process of meaning (significance) is important because human expresses meanings on the encountered reality. Semiotics is a branch of science that discusses how to understand symbols or interpret sign messages in communication. Semiotics deals with everything related to a sign. A sign is anything that can be used as a substitute for something else significantly [4].

According to Peirce, there are three types of sign relations: 1) iconic, signs based on their representational forms; 2) indexical, signs presupposing a casual or natural causal relationship between the expression and its contents; 3) arbiter; signs based on cultural knowledge [5].

This implies that language has a close relationship with reality. According to Peirce, a sign is created by human cognition dynamically [6].

simulation does not cover reality, but reality covers emptiness. Therefore, the simulation is real. There are four images of appearance, which have shaped Western culture, namely realistic; an actual situation, and counterfeit; a natural stage which can be found through imitation, production, and simulation which covers simulacra from simulation, information generation, and code. Image one to three had occurred in the previous years. Meanwhile, the fourth image is a simulation that depicts people's lives today. In conclusion, there is no more basic reality to which objects and signs refer and this is the era of hyperreality.

Cak or Kecak, one of the arts, which has become the pride of Indonesia originating from Bali, is a dance that tells a Ramayana story and how each component is related to one another. 
Kecak dancers, who are mostly men, make a sound or an acapella to accompany the Ramayana dance. Ramayana has the most famous story about the kidnapping of Shinta by Rahwana but was saved by Rama, Shinta's love. The drama tells us about kidnapping, heroism, sacrifice, sincerity, and struggle. This is an artificial world where all values are glorified, simulated, and presented to the audience [7].

\subsection{Dance Learning for Male Students}

Dance Learning is two words to describe dance activities that are generally performed by women for entertainment or an offering to God Almighty. Many citizens today think that dancing is only performed by women and are considered to have feminist movements. Learning dance in schools, especially in Vocational High School, where the majority of students are male, is not merely an activity to explore the feminist movements as in general. However, dance learning at Vocational and Senior High Schools is to stimulate, manage the feeling/sensitivity and imagination of students, and enrich arts knowledge in Indonesia related to the response to arts and aesthetics.

Even arts education can develop and improve students' creativity to explore dance movements in artistic practice, so the students could express themselves, be creative to generate ideas in the form of works representing personal feelings. One of the advantages of dance learning is that students can express unique movements, while the disadvantage is that students are not able to construct movements based on the characters and floor patterns.

The results of dance learning on exploration and improvisation materials are types of movement, movement characters, and kinds of drama, which are suitable for the male students at Grade XI Computer and Network Engineering. This study explains the learning outcomes of exploration and improvisation materials through a Ramayana story presented in a drama. The dance learning on exploration and improvisation materials use a constructivist theory that emphasizes experiences, restructuring, new ideas, and reviews.

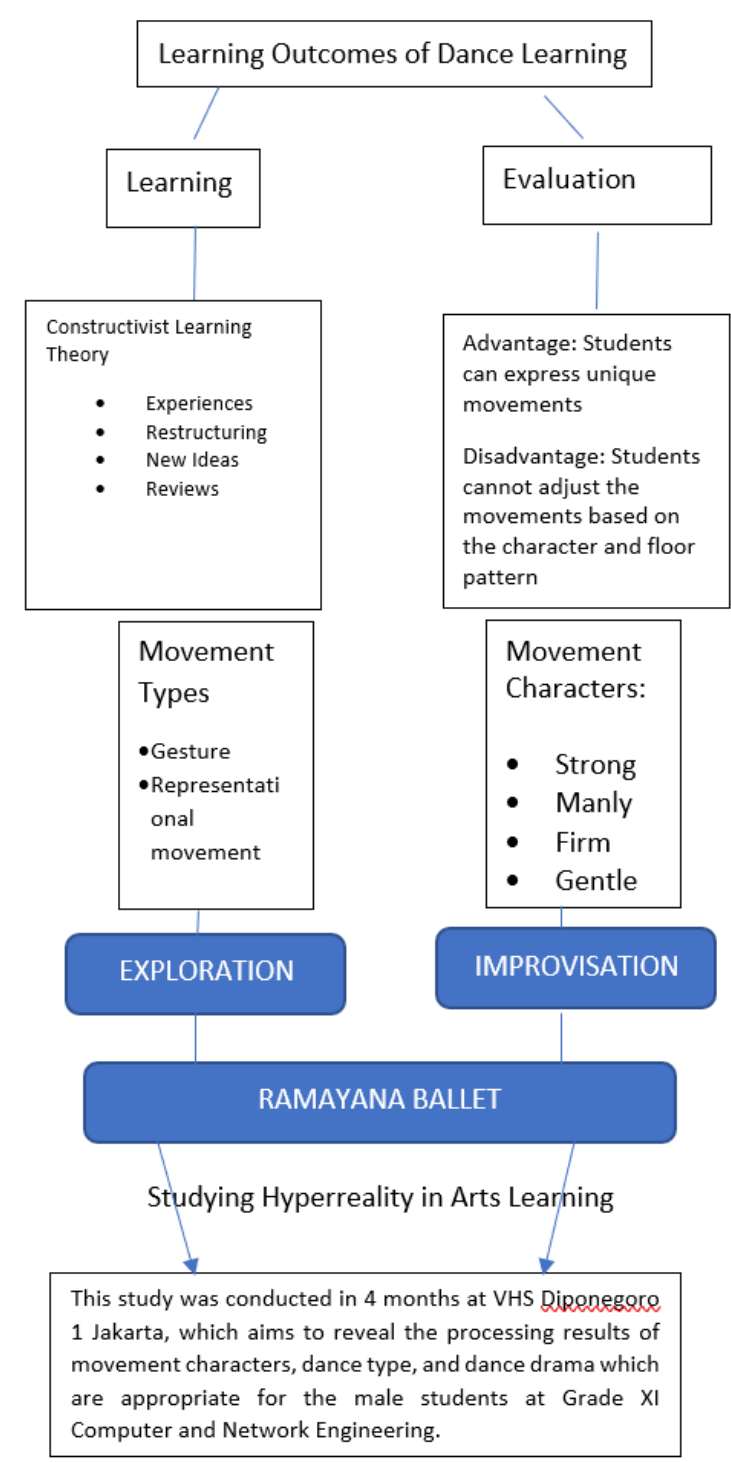

Figure 1 Conceptual Framework in Dance Learning

The type of movement is divided into two: gesture and representational movements, while the characters are strong, manly, firm, and gentle. The type of drama about Ramayana belongs to ballet which has supporting elements such as theme, title, script, storyline, movement, musical accompaniment, makeup, and fashion. The learning outcomes can be noticed in the Ramayana ballet performance. The explanation below is the use of a conceptual framework.

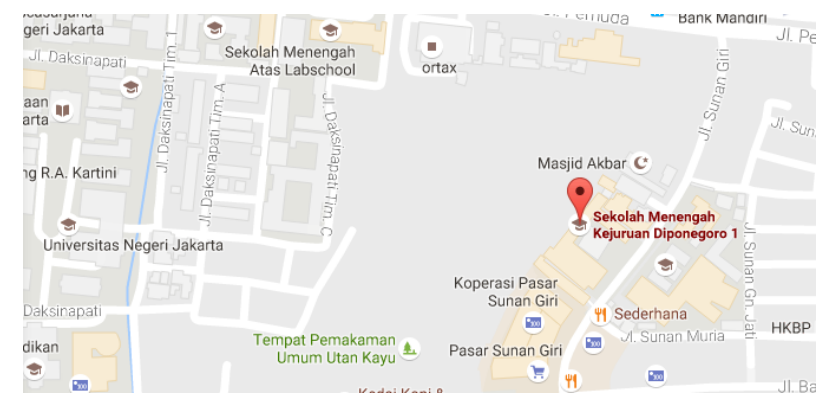

Figure 2 Research Location 


\subsection{Outcomes of Dance Learning in Charles Sanders Pierce's Semiotics}

This study employed a semiotics approach by Charles Sanders Peirce. Peirce [6] states that "through signs, humans can interpret life with reality". The most important thing that cannot be separated from the Peirce's theory on trichotomies is the relationship between Interpretant, Object, and Representamen, where the sign is an inseparable part of the object of reference and the subject's understanding of the sign [6]. Based on the experts' theories and opinions that have been mentioned, the research employed a qualitative research method with a semiotic approach of Charles Sanders Peirce, which provides an overview of Hyperreality in Dance Learning for Grade XI Students in Computer and Network Engineering Program at VHS Diponegoro 1 Jakarta. The determination of the research method was carried out based on the research objectives described previously, in which the authors generally wanted to explore the Hyperreality in Dance Learning on male students, which was explained in the table of Charles Sanders Peirce's Trichotomic Semiotics as follows;

Table 1 Peircean trichotomies

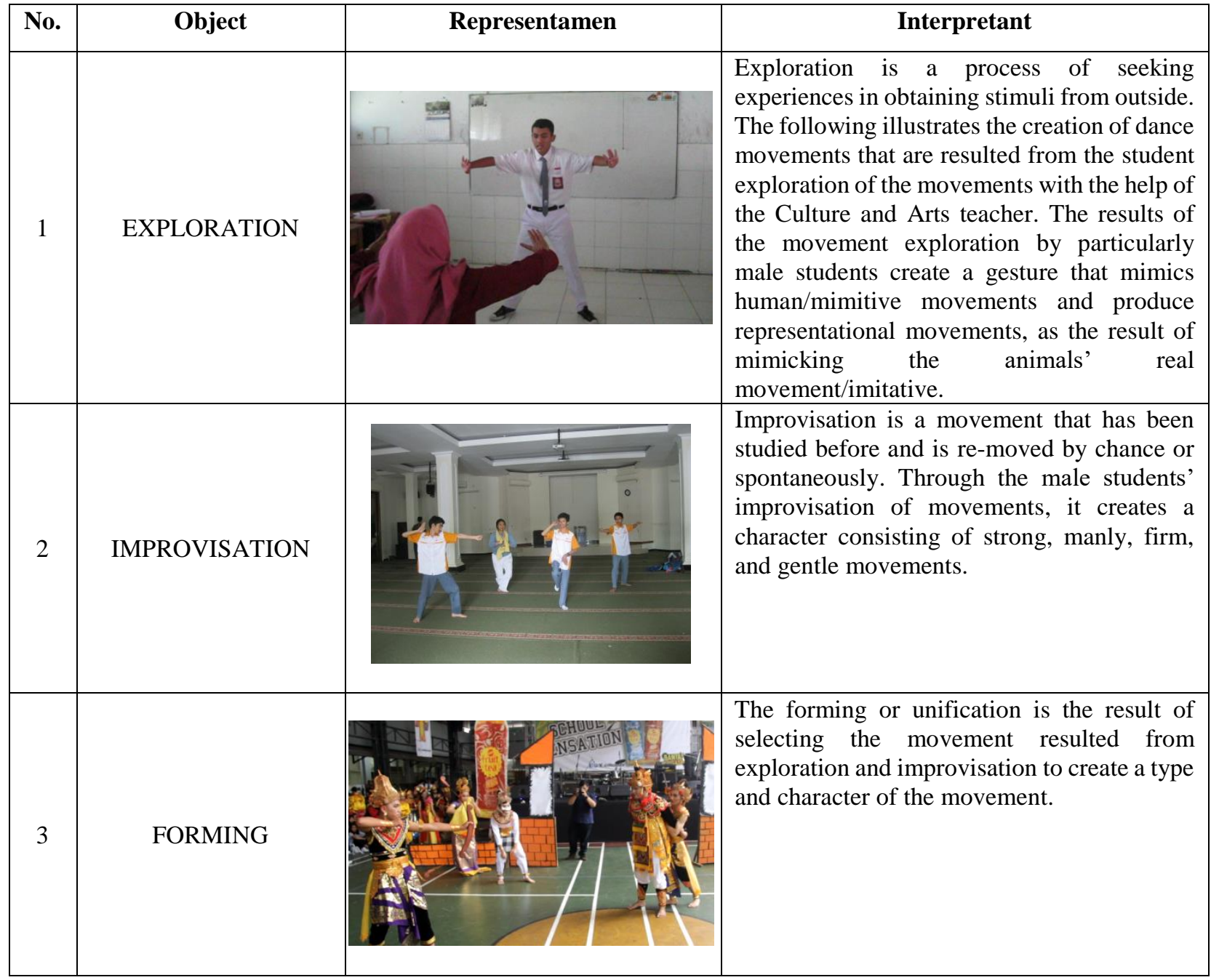

The result of the dance drama forming is the story of Ramayana with 13 characters that are suitable for teenagers at VHS Diponegoro 1 Jakarta. Dance movements from the results of students' exploration and improvisation meet the determined plot; a creative dance for vocational high school students is created and the floor pattern result from group dance is formed.

The type of dance that is obtained from the exploration and improvisation movement is a gesture that aims to imitate human movements adjusted to the character of each student. In addition, the representational movements, to imitate the animals' movements, such as the hanuman character performing the monkey animal, eagle character, and the deer character. Therefore, there are two types of movement obtained.

The movement character is divided into four: manly, strong, firm, and gentle. Three of them are masculine characters: manly, strong, firm, which are proper to be 
performed by the male students. Meanwhile, gentle or feminist movements are only played by a woman in the Ramayana ballet. The Ramayana ballet must have a dramatic structure to present a story which does not seem to be monotonous. Improvisation supports the forming with spontaneous results and hones the students' skills; the teacher plays an important role in helping students improvise the movements. The teacher beautifies the floor pattern after the students find the improvised results.

\section{CONCLUSIONS}

Hyperreality in dance learning especially for male students is very typical of thought that a man dancing is called a "sissy". The male students at VHS Diponegoro 1 Jakarta with exploration and improvisation movements prove their skills that they can move freely, be more confident in the dance subject, and be excited during the process of making a drama. The masculine characters that can be noticed from the male students' performance are strong, manly, and firm. The Ramayana story written by Walmiki (Valmiki) about Rama Wijaya's journey in taking back his love, Dewi Shinta, from the evil King Rahwana, was presented in a ballet performance. The Grade XI Computer and Network Engineering students can carry out dance learning at the stage of exploration, a process of finding movements by each student based on the character played.

Meanwhile, the improvisation is created based on the musical accompaniment. The success of this qualitative study is characterized by some aspects below:

1. The students carry out all activities attentively. They show a cooperative attitude with the teachers and researchers. Also, they provide full concentration during the implementation of learning activities.

2. The high intensiveness of a student activity is indicated when the students are actively involved in pouring ideas to make movements and give suggestions to the group, and when they perform the dance which is created by themselves.

3. The students show high motivation and enthusiasm, indicated by attentiveness during the learning process.

4. The students show better self-confidence through the performance of Ramayana ballet at a school event, i.e. the Three-Unit Arts Performance at VHS Diponegoro 1 Jakarta.

\section{REFERENCES}

[1] Sugiono, Metode Penelitian Pendidikan [Educational Research Methods]." Bandung, Alfabeta, 2018 .

[2] Wiliam, D, Comments on bulterman-bos:what should education research do, and how should it do it? Educational Researcher, 37(7) (2008) 432-438. https://doi.org/10.3102/0013189X08325678

[3] Sukardinata, Nana Syaodih, "Metode Penelitian Pendidikan [Educational Research Methods]." Bandung, Remaja Rosdakarya, 2009.

[4] Eco, Umberto, "Teori Semiotika [Semiotic Theory]." Yogyakarta, Kreasi Wacana Yogyakarta, 2009.

[5] Denzin. Norman K, "Post Moderns Social Theory". Jurnal Sociological Theory, 4 (2) (1986) 194-204. https://www.jstor.org/stable/201888?seq=1

[6] Dadan Rusmana, "Filsafat Semiotika [the Philosophy of Semiotic].” Bandung, CV Pustaka Setia, 2014.

[7] Jean Baudrillard, Simulacra and Simulation, United State of America: The University of Michigan Press. 1983. 